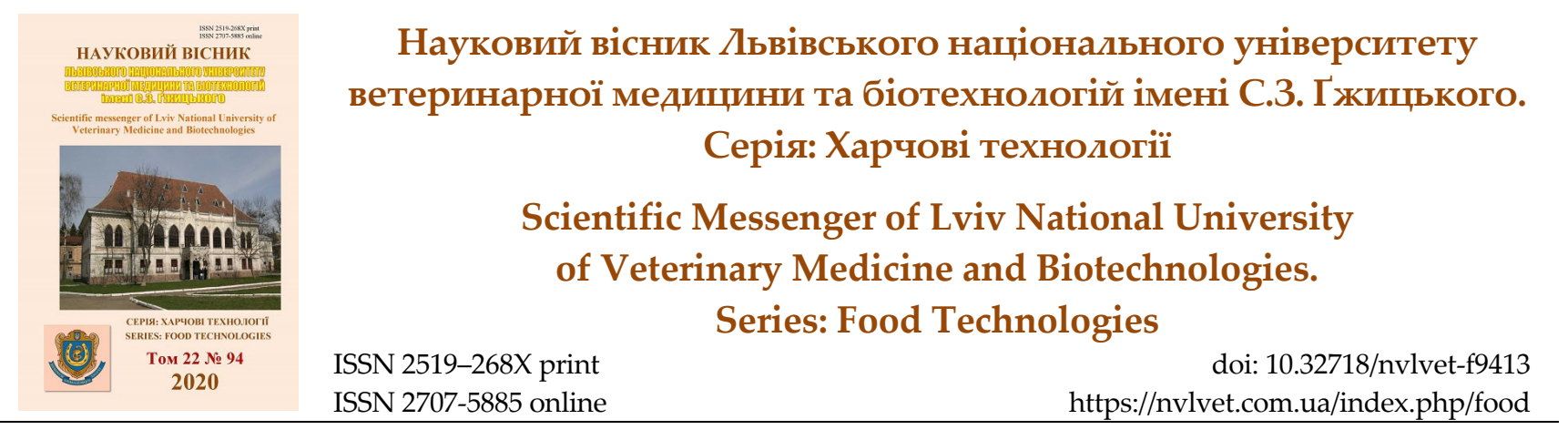

UDC 637.143.6

\title{
Improvement of technology of melt butter with turmeric
}

\author{
D. S. Lyhovid, N. B. Slyvka, O. Ya. Bilyk, I. V. Skulska \\ Stepan Gzhytskyi National University of Veterinary Medicine and Biotechnologies Lviv, Ukraine
}

Article info

Received 10.09.2020

Received in revised form 12.10.2020

Accepted 13.10.2020

Stepan Gzhytskyi National University of Veterinary Medicine and Biotechnologies Lviv.

Pekarska Str., 50, Lviv, 79010, Ukraine.

Tel.: +38-067-275-37-25

E-mail:slyvkanat@ukr.net
Lyhovid, D. S., Slyvka, N. B., Bilyk, O. Ya., \& Skulska, I. V. (2020). Improvement of technology of melt butter with turmeric. Scientific Messenger of Lviv National University of Veterinary Medicine and Biotechnologies. Series: Food Technologies, 22(94), 66-70. doi: 10.32718/nvlvet-f9413

The aim of the work was to improve the technology of melt butter with turmeric and to study the quality indicators of the finished product. The experiments were conducted in the laboratory of the Department of Milk and Dairy Products Technology of Stepan Gzhytskyi National University of Veterinary Medicine and Biotechnologies Lviv. The study was conducted in two stages. At the first stage, a natural source of antioxidants for melt butter was selected, the optimal amount for application was selected and the technology of melt butter with turmeric was improved. In the second stage of research, the quality indicators of the finished product were determined. Ways to improve the stability of melt butter during storage are analyzed and the possibility of using vegetable raw materials, namely turmeric powder in melt butter technology, is substantiated. Turmeric contains vitamins $K, B, B 1, B 2, C, D$ and minerals, including calcium, iron, phosphorus and iodine, as well as essential oils and their components - sabinene, borneol, cigiberren, terpene alcohols, phelander, curcumin and others. components that, even in microscopic quantities, have a good effect on the human body. Modes of technological operations are described. Turmeric powder is added to the fat fraction obtained as a result of separation, which is sent to intermediate baths and incubated for 1-2 hours. at a temperature of 90-95 ${ }^{\circ} \mathrm{C}$, stirring every 5-7 minutes. This creates a specific taste and aroma of melt butter and reduces the emulsification ability of the system, which improves the efficiency of subsequent separation. The optimal dose of turmeric powder is $0.5 \%$ by weight of the fat fraction. Selected to obtain a homogeneous consistency of the finished product, the cooling temperature is not higher than 14-18 ${ }^{\circ} \mathrm{C}$. Organoleptic and physicochemical parameters of the finished product are described. Organoleptic characteristics of melt butter during storage (two months) did not change significantly. The acidity of the fatty phase during storage increased and amounted to $1.82-1.93{ }^{\circ} \mathrm{K}$ at a maximum allowable value of $2.4^{\circ} \mathrm{K}$, due to the influence of antioxidant properties of turmeric.

Key words: melt butter, turmeric, technology, antioxidants.

\section{Удосконалення технології топленого масла з куркумою}

\author{
Д. С. Лиховід, Н. Б. Сливка, О. Я. Білик, І. В. Скульська
}

Львівський національний університет ветеринарної медицини та біотехнологій імені С. 3. Гжицького, м. Львів, Україна

Метою роботи було удосконалення технології топленого масла із куркумою та вивчення показників якості готового продукту. Досліди проведено у лабораторії кафедри технологї̈ молока і молочних продуктів Львівського національного університету ветеринарної медицини та біотехнологій імені С. З. Гжицького. Дослідження проводили у два етапи. На периому етапі здійснювали вибір природного джерела антиоксидантів для топленого масла, підбирали оптимальну кількість для внесення та удосконалювали технологію топленого масла із куркумою. На другому етапі досліджень визначали показники якості готового продукту. Проаналізовано шляхи поліпшення стабільності топленого масла під час зберігання та обтрунтовано можливість використання рослинної сировини, а саме порошку куркуми в технологї топленого масла. Куркума містить вітаміни К, B, B1, B2, C, D і мінеральні речовини, зокрема кальцій, залізо, фосфор і йод, а також ефірні олії та їх компоненти - сабінен, борнеол, ицигіберрен, терпенові спирти, феландр, куркумін та ряд інших компонентів, які навіть у мікроскопічних кількостях добре впливають на організм людини. Описано режими технологічних операцій. Порошок куркуми вносять в отриману в результаті сепарування жирову фракцію, яку направ- 
ляють у проміжні ванни і витримують 1-2 год. при температурі 90-95 ${ }^{\circ}$ С, перемішуючи кожні 5-7 хв. При иьому формується специфічний смак і аромат топленого масла та знижується емульгаційна здібність системи, щзо покращує ефективність наступного сепарування. Оптимальна доза порошку куркуми - 0,5 \% від маси жирової фракції. Обрано для отримання гомогенної консистенції готового продукту температуру охолодження не вище 14-18 ${ }^{\circ} \mathrm{C}$. Описано органолептичні та фізико-хімічні показники готового продукту. Органолептичні показники топленого масла під час зберігання (двох місячів), не зазнали істотних змін. Кислотність жирової фази впродовж зберігання наростала і становила 1,82-1,93 ${ }^{\circ} \mathrm{K}$ при максимально допустимому значенні 2,4 К, шео пояснюється впливом антиоксидантних властивостей куркуми.

Ключові слова: топлене масло, куркума, технологія, антиоксиданти.

Вступ

Широко відомим молочним продуктом є вершкове масло - високожирний харчовий продукт, який виготовляють із вершків молока. Воно повинно містити $52 \ldots 82,5 \%$ жиру, $16 \ldots 35 \%$ вологи та $1 \ldots 13 \%$ сухого знежиреного молочного залишку. Завдяки своєму складу (велика кількість низькомолекулярних жирних ненасичених кислот) має низьку температуру плавлення $\left(+28 \ldots+35^{\circ} \mathrm{C}\right)$ і добре засвоюється організмом (Petrova, 2014). Слід зазначити, що асортимент вершкового масла в Україні порівняно небагатий. Це солодковершкове масло та масло вершкове 3 наповнювачами (здебільшого 3 какао). За кордоном в останні роки виробляють широкий асортимент продуктів 3 високим вмістом молочного жиру, таких як топлене масло та молочний жир.

Топлене масло - один 3 найпопулярніших традиційних молочних продуктів в Індії. Починаючи 3 ведичної ери, його використовували для релігійних обрядів, кулінарії, косметичних та лікувальних цілей. Значення топленого масла в індійських дієтах було визнано ще 3 доісторичних часів через його високу поживну цінність, приємний аромат та текстурні властивості. Приблизно одна третина всього молока, виробленого в Індії, використовується для виготовлення топленого масла - гхі. Виробництву топленого масла в Індії сприяє найкраще використання невикористаного молочного жиру; простота зберігання без охолодження; тривалий термін зберігання; низька вартість і прості технології (Hazra \& Parmar, 2014).

Різні наукові дослідження свідчать про те, що характерний смак топленого масла та суміші біологічно активних сполук роблять його придатним для вживання людям різного віку для досягнення покращення здоров'я. Біофункціональні властивості топленого масла вирізняють його серед інших молочних продуктів. Топлене масло сприяє довголіттю і захищає організм від різних захворювань, стимулює процеси всмоктування і засвоєння їжі, покращує пам'ять і зір, зміцнює мозок та нервову систему, сприяє регенерації клітин, підсилює обмін речовин в тканинах (Tirtha \& Bayville, 1998; Lad, 1998).

Топлене масло активно використовується в Аюрведі для численних медичних застосувань, включаючи лікування алергії, шкірних та респіраторних захворювань. Багато аюрведичних препаратів - це лікарські рослини в топленому маслі. Топлене масло транспортує лікувальні властивості трав до глибоких тканинних шарів організму. Правильне всмоктування та постачання до органів-мішеней мають вирішальне значення для отримання максимального ефекту від будь-якого терапевтичного препарату (Sharma, 1990).
Хімічно топлене масло - це складний ліпід гліцеридів (переважно тригліцеридів), вільних жирних кислот, фосфоліпідів, стеринів та їх ефірів, жиророзчинних вітамінів (A, D, E та K), каротиноїдів, карбонільних сполук, вуглеводнів, вологи і слідів мікроелементів (Tjutjunnikov, 1992).

Відомо, що ліпіди під час одержання та зберігання зазнають різних змін. Продукти хімічних перетворень ліпідів, що виникають унаслідок реакцій окиснення, термополімеризації, циклізації, взаємодії жиру з водою та харчовими інгредієнтами, істотно погіршують харчові властивості та якість ліпідів (Brainina et al., 2011; Tsykhanovska et al., 2017).

Окислювальна прогірклість - основна причина погіршення якості топленого масла. Основними шляхами поліпшення стабільності топленого масла є згодовування дійним тваринам специфічних кормів, зміна параметрів технологічної обробки, використання відповідних пакувальних матеріалів та дотримання умов зберігання, додавання синтетичних антиоксидантів, застосування спецій та приправ, ароматичних трав тощо (Tsisaryk, 2009; Srivastava \& Singh, 2019). Численні дослідження застосування природних антиоксидантів при виробництві жировмісних продуктів зумовлені засторогою медицини щодо потенційних тератогенних, канцерогенних та мутагенних ефектів від використання синтетичних антиоксидантів (Hazra \& Parmar, 2014).

Сік плодів амли (Emblica officinalis) завдяки високому вмісту аскорбінової кислоти та галатів має помітну антиоксидантну властивість та при додаванні до топленого масла у кількості 1,25 \% запобігає прогірканню готового продукту (Ahmad et al., 1960). Є дослідження впливу на окислювальну стабільність топленого масла додавання чотирьох ароматичних трав, а саме розмарину (Rosmarinus officinalis), шавлії (Artemisia herballa), кропу (Foeniculum vulgare) та рути (Rutagra veatons). Їх додавали в топлене масло у кількості 7,5 \%. Всі ці трави мали антиоксидантну дію протягом перших 24 годин зберігання (Amr, 1996). Ядра насіння манго (Mangifera indica) містять фосфоліпіди, фенольні сполуки стерини, вітамін $\mathrm{C}$, каротин. Висушений порошок ядра насіння манго вносили у кількості 1,0..2,5\% у топлене масло і це позитивно впливало на його окислювальну стабільність (Parmar et al., 2013). Фосфоліпіди із насіння соняшнику (Helianthus annuus), apaxicy (Arachis hypogaea) та бавовнику (Gossypium hirsutum) є потужним антиоксидантом для топленого масла (Bhatia et al., 1978). Високі антиокислювальні властивості має екстракт коріандру (Coriandrum sativum). Дослідженнями встановлено його позитивний вплив на якісні показники топленого масла під час зберігання (Patel et al., 2013). 
Тому пошук нових джерел біоантиоксидантів для розширення асортименту жировмісних продуктів, зокрема і топленого масла, є актуальним. Адже природні антиоксиданти здатні впливати на органолептичні показники готового продукту, а в деяких випадках можуть також забезпечити додаткову харчову цінність.

Куркума - це рослина, яка відноситься до родини Імбирних. Нині науковці виділяють більше 90 видів цього кореня, проте найбільш досліджений і знайшов широке використання у харчових технологіях як спеція куркума довга (Curcuma longa). Існують і інші назви цього кореня, зокрема куркума домашня (Curcuma domestica), або турмерик чи жовтий корінь. Ця спеція надає стравам приємного гострого смаку і специфічного аромату та жовтого кольору. Куркума містить вітаміни К, В, В1, В2, C, D і мінеральні речовини, зокрема кальцій, залізо, фосфор і йод, а також ефірні олії та їх компоненти - сабінен, борнеол, цигіберрен, терпенові спирти, феландр, куркумін та ряд інших компонентів, які навіть у мікроскопічних кількостях добре впливають на організм людини. Вона виявляє протизапальну, антибактеріальну, антиоксидантну, нематоцидну, антипаразитарну, спазмолітичну та антиканцерогенну активність (Niranjan \& Prakash, 2008).

Метою роботи було удосконалення технології топленого масла із куркумою та вивчення показників якості готового продукту.

\section{Матеріал і методи досліджень}

Масло топлене виготовляли комбінованим способом. Сутність способу полягає у розплавленні масла вершкового та витримуванні його в резервуарівідстійнику, а потім сепаруванні для відділення плазми. Топлене масло пакували в скляну тару ємністю 200 мл та зберігали в холодильнику за температури $+4{ }^{\circ} \mathrm{C}$ впродовж 35-ти діб.

\section{Таблиця 1}

Органолептичні показники топленого масла із куркумою

\begin{tabular}{|c|c|c|c|c|}
\hline \multirow{2}{*}{ Показники } & \multirow{2}{*}{ Контроль } & \multicolumn{3}{|c|}{ Вміст куркуми, \% } \\
\hline & & 0,5 & 1,0 & 1,5 \\
\hline Консистенція & $\begin{array}{c}\text { щільна, гомогенна маса, у } \\
\text { розтопленому стані - } \\
\text { прозора, без осаду }\end{array}$ & \multicolumn{3}{|c|}{$\begin{array}{c}\text { м’яка консистенція, без зернистості, у розтопленому стані - прозора, без } \\
\text { осаду }\end{array}$} \\
\hline Аромат і смак & $\begin{array}{l}\text { чистий, добре виражений, } \\
\text { характерний для витопленого } \\
\text { молочного жиру }\end{array}$ & $\begin{array}{l}\text { чистий, } з \text { ніжним арома- } \\
\text { том і характерним прис- } \\
\text { маком куркуми }\end{array}$ & $\begin{array}{c}\text { чистий, з вираженим } \\
\text { ароматом і характер- } \\
\text { ним гіркуватим прис- } \\
\text { маком куркуми }\end{array}$ & $\begin{array}{l}\text { чистий, з різким запа- } \\
\text { хом куркуми, терпкий } \\
\text { і гіркуватий смак }\end{array}$ \\
\hline Колір & $\begin{array}{c}\text { світло-жовтий, однорідний за } \\
\text { всією масою }\end{array}$ & золотисто-жовтий, одн & рідний за всією масою & $\begin{array}{l}\text { темно-жовтий, одно- } \\
\text { рідний за всією масою }\end{array}$ \\
\hline
\end{tabular}

3 табл. 1. видно, що найкращий смак і аромат має топлене масло із внесенням порошку куркуми у кількості 0,5 \%. Отримана консистенція топленого масла 3 куркумою пояснюється швидким його охолодження до температури $14 \ldots 18{ }^{\circ} \mathrm{C}$ і утворенням більшої кіль-
Як біологічно активну добавку використовували порошок куркуми. Його вносили в топлене масло у кількості 0,5, 1,0 і 1,5 \% до маси жиру. Контролем слугувало топлене масло без добавки.

Дослідження проводили у два етапи. На першому етапі здійснювали вибір природного джерела антиоксидантів для топленого масла, підбирали оптимальну кількість для внесення та удосконалювали технологію топленого масла із куркумою.

На другому етапі досліджень визначали показники якості готового продукту. Проби продукту зберігали впродовж 60-ти діб. На 1-шу, 20-ту, 40-у та 60-ту добу зберігання аналізували органолептичні показники масла - смак, запах, колір (ГОСТ 37-91). Визначення фізико-хімічних показників проводили згідно ГОСТ 5867 - масову частку жиру, ГОСТ 3626 - масову частку вологи. Кислотність жирової фази масла визначали у градусах Кетстофера $\left({ }^{\circ} \mathrm{K}\right)$, під якими розуміють об'єм 0,1 моль/дм ${ }^{3}$ розчину гідрооксиду натрію (калію), витраченого на нейтралізацію 5 г масла, помножений на 2.

\section{Результати та їх обговорення}

Аналіз літературних даних показав, що вживання продуктів зі спеціями зменшує інсулінову реакцію на $20 \%$ і на $13 \%$ збільшує антиоксидантну активність у крові. Крім того, окремі спеції можуть бути природними барвниками, зокрема куркума завдяки вмісту куркуміну надає продуктам яскраво - жовтого кольору. Оскільки куркумін добре розчиняється у жировій основі і не розчиняється у воді, як молочну основу для створення нового продукту було обрано топлене масло.

Основне завдання при конструюванні нового продукту полягало у підборі оптимальної кількості спеції. Важливим критерієм для споживача є органолептичні показники готового продукту. У табл. 1 представлено характеристику зовнішнього вигляду, запаху та смаку топленого масла із різним вмістом порошку куркуми. кості дуже дрібних кристалів, які складаються із сумішей жирів з високим та низьким плавленням.

Оскільки мінімальним терміном зберігання масла топленого у скляних банках згідно нормативних документів (ДСТУ 4399:2005 “Масло вершкове. Технічні умови”) є 2 місяці, то досліджували органолептичні 
показники на 1-шу, 20-ту, 40-у та 60-ту добу зберігання. Аналізуючи зміну органолептичних показників топленого масла впродовж зберігання, не встановлено істотних розходжень у дослідних зразках. Слід відзначити, що зміна смаку і запаху масла була зареєст- рована після 60-ої доби зберігання лише у контролі, при цьому появився нечистий аромат та окиснений смак.

Дослідження фізико-хімічних показників наведено у табл. 2.

Таблиця 2

Фізико-хімічні показники масла топленого з куркумою

\begin{tabular}{|c|c|c|c|c|c|}
\hline \multirow{3}{*}{$\begin{array}{c}\text { Зразки топленого } \\
\text { масла }\end{array}$} & \multirow{2}{*}{\multicolumn{4}{|c|}{ Масова частка, \% }} & \multirow{3}{*}{$\begin{array}{c}\text { Кислотність жирової } \\
\text { фази, }{ }^{\circ} \mathrm{K}\end{array}$} \\
\hline & & & & & \\
\hline & вологи & жиру & білка & мінеральних речовин & \\
\hline Контроль & $1,0 \pm 0,3$ & $98,0 \pm 0,9$ & $0,2 \pm 0,07$ & $0,8 \pm 0,05$ & $1,3 \pm 0,2$ \\
\hline 3 0,5% куркуми & $1,4 \pm 0,5$ & $97,5 \pm 0,8$ & $0,3 \pm 0,07$ & $0,8 \pm 0,05$ & $1,3 \pm 0,3$ \\
\hline 3 1,0% куркуми & $1,6 \pm 0,6$ & $97,2 \pm 0,8$ & $0,3 \pm 0,08$ & $0,9 \pm 0,06$ & $1,4 \pm 0,3$ \\
\hline 31,5 \% куркуми & $1,7 \pm 0,6$ & $97,0 \pm 0,7$ & $0,4 \pm 0,08$ & $0,9 \pm 0,04$ & $1,4 \pm 0,5$ \\
\hline
\end{tabular}

На початку зберігання кислотність жирової фази топленого масла становила $1,3 \ldots 1,4{ }^{\circ} \mathrm{K}$. Під час двомісячного зберігання у дослідних зразках кислотність наростала і становила $1,82 \ldots 1,93{ }^{\circ} \mathrm{K}$ при максимально допустимому значенні $2,4{ }^{\circ} \mathrm{K}$. Це можна пояснити високою температурою пастеризації жирової фракції при виробництві топленого масла $\left(90 \ldots 105{ }^{\circ} \mathrm{C}\right)$ та внесенням порошку куркуми, яка $є$ антиоксидантом. Хімічний склад топленого масла із куркумою впродовж зберігання не зазнав змін.

Особливості технології топленого масла із куркумою описано нижче.

Для виробництва топленого масла використовували масло солодковершкове масовою часткою жиру 72,5 \% без сторонніх присмаків та запахів, механічних домішок та включень.

Масло вивільняють 3 пергаменту і очищають від поверхневих забруднень. Далі його подрібнюють і розплавляють при температурі $65 \ldots 70{ }^{\circ} \mathrm{C}$ у ванніплавителі. Для часткового відділення плазми від молочного жиру витримують 1 год. при температурі $50 \ldots 5{ }^{\circ} \mathrm{C}$. Плазму, яка виділилась, насосом перекачують в проміжну ємкість. Жирову фракцію, відокремлену від плазми, з ванни-плавителя направляють в пастеризатор, де нагрівають до $95 \ldots 105^{\circ} \mathrm{C}$. Така обробка забезпечує повний розпад жиророзчинних ферментів та майже не викликає окислювальних процесів псування жиру. Далі розплавлену масу очищають від коагульованого білка i подають на сепарування. Отриману в результаті сепарування жирову фракцію направляють у проміжні ванни i витримують $1 \ldots 2$ год. при температурі $90 \ldots 95{ }^{\circ} \mathrm{C}$, перемішуючи кожні $5 \ldots 7$ хв. для запобігання пригорання білку до стінок ванни. Під час цієї технологічної операції формується специфічний смак і аромат топленого масла. Одночасно при цьому знижується емульгаційна здатність системи, що покращує ефективність наступного сепарування. На цьому етапі вносять порошок куркуми у кількості 0,5 \% від маси жирової фракції. Після витримки проводять друге сепарування для кінцевого видалення білка і вологи. Масова частка жиру у готовому продукті становить 99 \%. Для охолодження топленого масла з куркумою використовують пластинкові або циліндричні маслоутворювачі. Як споживчу тару для масла топленого з куркумою використовують скляні склянки масою нетто 200 г. Після фасу- вання топлене масло охолоджують. Для отримання зернистої структури топленого масла, однорідної по всій масі продукту, температура охолодження повинна бути $36 \ldots 40{ }^{\circ} \mathrm{C}$, а для отримання гомогенної консистенції $-14 \ldots 18^{\circ} \mathrm{C}$.

\section{Висновки}

1. Розглянуто доцільність використання спецій у технології топленого масла, а саме порошку куркуми.

2. Удосконалено технологію топленого масла із куркумою. Оптимальна доза внесення спеції 0,5 \%, що дає змогу підвищити стійкість продукту до окиснення під час зберігання, забезпечує кращі смакові якості та розширює асортимент біологічно повноцінних жировмісних продуктів.

3. Досліджено основні фізико-хімічні показники готового продукту.

4. Топлене масло з куркумою - продукт тривалого зберігання, який дозволяє розширити асортимент продуктів підвищеної харчової цінності.

Перспективи подальших досліджень. Отримані результати зумовили такі напрями подальших досліджень: дослідження в динаміці чутливості до окиснення топленого масла із куркумою; дослідження змін мікробіологічних показників та проведення його промислової апробації.

\section{References}

Ahmad, I., Karimullah, M. K. N., \& Saeed, M. K. (1960). A comparative study of amlaproducts and synthetic antioxidant for edible fats. Pakistan Journal of Science Research, 12, 71.

Amr, A. S. (1996). Role of some aromatic herbs on extending the stability of sheep ghee during accelerated storage. Egyptian Journal of Dairy Science, 18(2), 334-344. URL: http://eacademic.ju.edu.jo/ayedamr/Lists/Published $\%$ 20Research/DispForm.aspx?ID=8\&ContentTypeId=0x 010400A6D9F4C06D4669488056ED91AF4EF8E3.

Bhatia, I. S., Kaur, N., \& Sukhija, P. S. (1978). Role of seed phosphatides as antioxidants for ghee (Butter fat). Journal of the Science of Food and Agriculture, 29(9), 747-752. doi: 10.1002/jsfa.2740290903.

Brainina, Kh. Z., Gerasimova, E. L., Kasaimna, O. T., \& Ivanova, A. V. (2011). Antioxidant activity evaluation 
assay based on peroxide radicals generation and Potentiometrie measurement. Analitical Letters, 44(8), 1405-1415. doi: 10.1080/00032719.2010.512687.

Hazra, T., \& Parmar, P. (2014). Natural Antioxidant Use in Ghee-A Mini Review. Journal of Food Research and Technology, 2(3), 101-105. URL: http://jakraya.com/journal/pdf/5-jfrtArticle 2.pdf.

Lad, V. (1998). New York: Harmony Books. The Complete Book of Ayurvedic Home Remedies.

Niranjan, A., \& Prakash, D. (2008). Chemical constituents and biological activities of turmeric (Curcuma longa L.)-a review. J Food Sci Technol, 45(2), 109-116.

Parmar, P., Kaushik, K., Devaraja, H. C., \& Singh, R. R. B. (2013). The effects of alcoholic extract of Arjuna (Terminalia arjuna.) bark on stability of clarified butterfat. Journal of Medicinal Plants Research, 7(35), 2245-2550. doi: 10.5897/JMPR2013.5114.

Patel, S., Shende, S., Arora, S., \& Singh, A. K. (2013). An assessment of the antioxidant potential of coriander extracts in ghee when stored at high temperature and during deep fat frying. International Journal of Dairy Technology, 66(2), 207-213. doi: 10.1111/1471-0307.12023.

Petrova, I. A. (2014). Osoblyvosti ekspertnoho doslidzhennia tekhnolohii vyrobnytstva masla vershkovoho pry vy- iavlenni ekonomichnykh pravoporushen. Naukovi pratsi ONAKhT, 42(2), 269-273. URL: http://nbuv.gov.ua/ UJRN/Np 2014 46\%282\%29 70 (in Ukrainian).

Sharma, H. M. (1990). Butter oil (ghee) - Myths and facts. Indian J Clin Pract, 1, 31-32.

Srivastava, P., \& Singh, N. (2019). Utilization of natural antioxidant food processing waste material for oxidative stabilization of ghee. Asian Journal of Science and Technology, 4(5), 85-88. URL: http://www.foodsciencejournal.com/archives/2019/vol 4/issue5/4-5-25.

Tirtha, S. S., \& Bayville, N. Y. (1998). Ayurveda Holistic Center Press; 1998. The Ayurveda Encyclopedia.

Tjutjunnikov, B. N. (1992). Himija zhirov. 3-e izd., pererab. i dop. M.: Kolos (in Russian).

Tsisaryk, O. Y. (2009). Oksydantna stabilnist masla, vyhotovlenoho iz moloka koriv pry zghodovuvanni yim nasinnia ripaku. Visnyk Donetskoho natsionalnoho universytetu ekonomiky i torhivli imeni Mykhaila Tuhan-Baranovskoho, 1(41), 206-211 (in Ukrainian).

Tsykhanovska, I. V., Demydov, I. M., Aleksandrov, O. V., Hontar, T. B., \& Pavlotska, L. F. (2017). Doslidzhennia vplyvu biolohichno aktyvnoi dobavky na protsesy okysnennia lipidiv, 251-262 (in Ukrainian). 